\title{
IT'S TIME TO HEED TO NEW TECHNOLOGIES -- PHVA AND THE GHARIAL SITUATION
}

I hope you had an opportunity to visit our new web site www.zoosprint.org and left your valuable comments and suggestions for improving the magazine, journal and all the different network and miscellaneous publications. Many journals have now started publishing electronic versions that make accessibility easier, faster and better with benefit for all wildlife conservationists. With changes happening so rapidly to wild habitats, it is fortunate that there are new technologies to help us understand the consequences of our actions some time before experiencing our decimating capabilities in total. If we wait for years of hard data before acting in some situation, it may be too late to conserve rapidly diminishing biota. Population modelling is a relatively new technology that helps identify, in advance, the vagaries of human actions and the effects of pressures on a wild species in its natural habitat.

Modelling the Gharial population status along with Dr. R.J. Rao and D. Basu, some of the most experienced Gharial workers, at the PHVA was very exciting. The results countered the then recent policies of the state government described above and subsequent events have borne out the conclusions of the PHVA. It will be interesting to review the entire experience of the PHVA for Gharials held in Gwalior almost a decade ago.

The workshop held at that time made specific recommendations for the conservation of Gharials in the Chambal (listed in the next column). The model clearly indicated that if captive rearing and supplementation was discontinued, with the other habitat and population threats still in place, the populations of Gharial in the Chambal, Katerniaghat and Mahanadi all would crash and eventually become extinct. In the ensuing years since the PHVA, these threats were not addressed. In addition, the governments of Rajasthan, Madhya Pradesh and Uttar Pradesh discontinued the captive rearing and release efforts of Gharial in Chambal, which had proved effective in rebuilding and sustaining the population since inception of these activities. These two factors - neglect in addressing threats and curtailing "grow and release" programme has produced a downward spiral of the gharial population in Chambal from about 1200 in 1995 to approximately half that number today.

The mortality rates in the age classes up to 3 years is very high in Gharials, which makes the population vulnerable to other forces intrinsic to small population dynamics given the pressures on their declining numbers. The "grow and release" programme that was initiated in the late 1970s stemmed the decline of the wild population as the juvenile mortality was reduced by the efforts of the forest departments of the three states. Releasing 3-year old juveniles increased their ability to survive longer in the wild, thus increasing the population of the Gharial in Chambal and in Katerniaghat.

In the light of recent surveys and from the experience of techniques like the PHVA, one complementing the other, the forest departments are urged to resume captive rearing and release of Gharials. Simultaneously, the threats affecting the wild populations need to be addressed urgently and valiently for the Gharial to survive long in perpetuity in the wild.

While these recent trends ratify a methodology such as the PHVA, it is saddening that such methods are not taken more seriously in resolving crucial issues when there is still a chance of maximising options and minimising risks. Similar PHVAs for other animals such as Asiatic Lions, Lion-tailed Macaques and Sangai have recommended some very relevant points for action, which if followed, could help resolve critical situations in advance, and obviating the necessity of "crisis management", as in the case of the Gharial currently. We can only hope for a better future for gharial in this current extreme situation.
Recommendations at the Gharial PHVA (for all three populations) 1. Although the Chambal population has been studied extensively and for a long time, some of the basic biology is lacking still. Systematic monitoring of all gharials is crucial to know longevity, age of first reproduction and sex ratio.

2. Threats to the population is in the form of floods, agricultural practices, predation, fishing, etc. These must be studied in detail to understand the actual damage caused to the population. Such an understanding could be better quantified for simulation modelling.

3. The scenarios modelled with migration show no extinction. To understand completely the dynamics of the population, migration studies need to be carried out in detail.

4. The Chambal population seems to have stabilized, and is growing presently. However, to be able to better predict probabilities, monitoring and study of these populations and their movements will help in better understanding the dynamics. 5. According to the model, the population is now stable enough to withstand selective harvesting of upto 500 eggs every year for rearing and further releasing at alternate sites.

6. Gharial population upstream and those downstream may be quite close genetically because of the bottleneck the population underwent 20 years ago, and this needs to be verified by genetic testing. DNA fingerprinting is recommended for all the subpopulations to better understand genetic make up and gene flow.

7. Continuous supplementation should be carried out for the Katerniaghat population since the number of individuals are too small to be viable on their own. The carrying capacity of the habitat is also small for the population to remain stable once the numbers reach that.

8. Scientific monitoring of the population must be carried out once the juveniles are released.

9. Genetic studies of the population should be made to assess the degree of inbreeding the population has undergone. Genetic typing of certain identified individuals representing different age classes should be carried out.

10. If the population is not mixed with release from Chambal or Mahanadi, genetic affinity must be tested and such releases should be made to retain enough heterozygosity.

11. Hatching and rearing gharial young in the rearing centers has reduced mortality dramatically. Releasing younger juveniles results in high mortality in the wild. To avoid this, Gharial of age 4 years and above should be released. 12. The Mahanadi population has been supplemented continuously over the last 19 years. This has infact helped the population avoid total extinction. Though continuous supplementations were carried out, the population has not stabilized. This shows that grave threats are affecting the populations still. Even though the simulation model showed no extinctions in the populations, high degrees of threats can push this population to extinction. Supplementation must therefore be carried out.

13. Genetic studies of this population should be carried out to see the difference between the Chambal and Mahanadi gharials. If the two populations are found not to differ as much as to be classified as distinct subspecies, supplementation of the Chambal gharials should be taken up in Mahanadi. This would also increase heterozygosity in the Mahanadi population.

14. Monitoring and continuous studies of the existing and released gharials must be taken up to study population dynamics and the effects of pollution on the populations.

For further information on this topic I refer readers to:

Anon (2004). Gharial reach a crisis in Chambal River. Crocodile Specialist group Newsletter 22(4): 12-13.

Rao, R.J., D. Basu, S.M. Hassan, B.B. Sharma, S. Molur and S. Walker (Editors) (1995). Population and Habitat Viability Assessment (PHVA) Workshop for Gharial - Report. Zoo Outreach Organisation, CBSG India, Coimbatore, 106pp (available online at www.zoosprint.org)

Sanjay Molur Editor

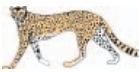

Visit www.zoosprint.org for on line version of the journal and for supplements 